Journal of Curriculum and Instruction (JoCl), July 2007, Volume 1, Number 1 (Stephanie G. Davis and Erika S. Gray)

\title{
Going Beyond Test-Taking Strategies: Building Self-Regulated Students and Teachers
}

\author{
Stephanie G. Davis \\ Erika Swarts Gray \\ University of North Carolina at Greensboro
}

Since the inception of No Child Left Behind (NCLB), standardized tests have been on the minds of students, parents, and educators, who are consistently concerned with how to increase test scores. In this article, the authors suggest that it is time to look beyond tests to enable willing, focused, and persistent - that is self-regulated - students and teachers. Self-regulated students and teachers take control of their learning, set goals, monitor progress, reflect on outcomes, are intrinsically motivated to learn, and demonstrate higher levels of achievement (Harter, 1996; Markman, 1979; Mason, Snyder, Sukhram, \& Kedem, 2006; Perry, Nordby, \& VandeKamp, 2003; Zimmerman, 2000, 2002). Supporting such self-regulation not only promotes more independent, competent, and motivated students and teachers, but is also likely to raise test scores (Paris \& Paris, 2001). The authors suggest specific strategies for, and benefits of, the development of selfregulation in both students and teachers.

\section{Introduction}

Since the inception of No Child Left Behind (NCLB), standardized tests have been on the minds of students, parents, and educators. A persistent concern has been, "What can we do to increase test scores?" Unfortunately, many schools turn to published test preparation material as the sole means to increase test scores; however, we argue here for a broader outlook that also includes developing students and teachers who are willing, focused, and persistent.

Such students and teachers are self-regulated. They take control of their learning. They set goals, monitor progress, reflect on outcomes, and are intrinsically motivated to learn (Perry, et al., 2003; Zimmerman, 2002). Previous research suggests that the ability to self-regulate one's learning is correlated to higher levels of achievement (Harter, 1996; Markman, 1979; Mason et al., 2006; Schunk, 2005; Zimmerman, 2000); therefore, helping students become selfregulated not only promotes more independent, competent, and motivated students and teachers, but is also likely to raise test scores (Paris \& Paris, 2001; Schunk \& Rice, 1991).

\section{Role of High-Stakes Testing in Literacy Instruction}

The focus on self-regulated motivation is extremely valuable in the area of literacy. It is precisely self-regulated learning that sustains and deepens engaged reading and consequent comprehension. That is, the motivational goals of choice, effort, and persistence are significant aspects of self-regulation. Selfregulated tasks such as reading for pleasure, connecting to prior experiences, and synthesizing ideas on one's own, are pivotal to nurturing the self-regulated engagement that may actually contribute to improved test scores. Without such 
Journal of Curriculum and Instruction (JoCl), July 2007, Volume 1, Number 1 (Stephanie G. Davis and Erika Gray)

motivation, students will be less likely to invest the effort it takes to comprehend and achieve.

Because meaning making is at the heart of reading comprehension, we must recognize and engage all that students bring with them to the task of learning (Au, 1997). This means that we encourage students to use the language they have to interpret texts, that they are encouraged to use their past experiences to understand information, and that we accept their differences. Au stresses the importance of students developing ownership of literacy, which means students value literacy and are willing to make literacy a part of their everyday lives. Galda and Guice (1997) state, "As we read we call upon what we know of the actual world to help us make meaning of the text" (p. 312).

As we think about less mature readers and how they gain this type of skill, we must take into account several factors. Some suggest that strategy instruction leads to student motivation because it assists them in knowing how to interpret texts; others say that motivation will lead to student engagement, which will lead to students' successful use of strategies during reading (Guthrie et al., 2004). No matter how the mechanism that connects self-regulated motivation to reading is understood, research demonstrates an important correlation between motivation and comprehension of texts. We know that readers must use self-regulated strategies to fully employ their ability to interpret or make meaning of texts. Developing such self-regulated skill holds benefits for many educational tasks, not the least of which is increased test scores (Mason, et al., 2006; Pintrich \& DeGroot, 1990).

\section{Developing Self-Regulated Learners}

\section{Motivation and Goals}

In school and in life, goals are what motivate, direct, or energize individual performance (Ames, 1992). Because goals are significant to self-regulated learning (Zimmerman, 2002), educators must understand which goal orientations are most beneficial to student engagement and how to support those orientations. Ames describes two main types of goals: mastery goals and performance goals. Mastery goals focus on understanding, developing competency, and achieving based on self-supporting standards. Students who are driven by mastery goals are driven to understand what they are learning and are willing to exert the effort needed to achieve their goal (Ames; Brophy, 1987).

For instance, a student who works on a task and is excited by new learning is mastery oriented. As a result, these students spend more time engaged in learning and are intrinsically motivated to learn. Thus, they are more likely to selfregulate and invest in their own learning (Pintrich \& DeGroot, 1990).

In contrast, performance goals are focused on competition with others and success is tied to a student's sense of self-worth. When students are driven by 
performance goals they want others to think they are competent. This goal orientation is not wrong; however, these types of goals have shown short-term results, including competition among peers and a tendency to avoid failure by not taking academic risks (Ames, 1992; Blumenfeld, 1992; Dweck \& Reppucci, 1973; Harter, 1996; Kaplan \& Maehr, 2002; Pintrich, 2000). These behaviors are associated with extrinsic motivation. Too much extrinsic motivation can be detrimental to self-regulated learning because outcomes are outside of students' control (Pintrich, 2000).

Goals driven by high-stakes testing are based on the need to perform, rather than on an intention to master content or expand thinking. Unfortunately, researchers have found a shift from a predominately intrinsic orientation to a more extrinsic motivation orientation during the major testing years of students' lives (Harter, 1996; Midgley, Feldlaufer \& Eccles, 1988). Moving beyond this narrow focus provides greater opportunities for students to become more selfregulated (Paris \& Paris, 2001).

\section{Self-Regulation}

Students who have autonomy and control over their reading have opportunities to become self-regulated and exercise a focus on mastery goals. Self-regulated readers monitor and adjust their behavior to support their individual learning needs.

Zimmerman $(2000,2002)$ suggests a cyclical model of self-regulation consisting of three phases: forethought, performance, and self-reflection. Students in the forethought phase use goal setting and strategic planning to selfregulate. For instance, students could create a plan to finish a chapter or a book. During the performance phase self-regulated students show self-control through self-instruction, imagery, focusing attention, and task strategies. During reading, students in this phase use their background knowledge and selective strategies to understand and comprehend the text. This could also include working with others and having conversations to better understand texts. Finally, students' self-reflection brings them back to evaluate and understand their own performance. That is, did they complete what they set out to accomplish and what is the next step? As will be discussed, considering individual choice in reading, open-ended reading tasks, and opportunities to evaluate one's work are important strategies for teachers to employ when encouraging the development of self-regulation among their students (Perry \& VandeKamp, 2000). See Figure 1 for an example of a self-regulated student's experience. 
Journal of Curriculum and Instruction (JoCl), July 2007, Volume 1, Number 1 (Stephanie G. Davis and Erika Gray)

Figure 1

\section{Marie: A Self-Regulated Learner}

Marie, a fourth grader, enters the classroom and notices her class is going to read about animals in a state zoo. Marie loves animals and wants to be a veterinarian. As her class moves to their guided reading groups, Marie notices three sets of books on her group's table. The group gets to choose among kangaroos, black bears, and polar bears. Marie's group enthusiastically chooses polar bears and begins to discuss with their teacher what they plan to learn by reading the book.

Marie's teacher, Mrs. Smith, could give them a task that is easy to achieve, or she could create a task with moderate challenge that the students can complete with some support. If she wants to expand Marie's understanding of her learning process, she will choose a moderately challenging task. Vygotsky (1978) refers to appropriate challenge level as a student's zone of proximal development. The benefits of moderately challenging tasks have been supported in research for over thirty years (Brophy, 1987; Csikszentmihalyi, 1975; Miller, 2003; Miller \& Meece, 1999; Perry, Philips, \& Dowler, 2004; Pintrich \& DeGroot, 1990; Rohrkemper \& Corno, 1988).

Mrs. Smith gave students a moderately challenging task. At the end of the week, even though she was confident Marie had mastered the standard she was striving to teach, she felt an assessment was needed. Since Mrs. Smith observed the investment Marie put into the task, she felt including Marie in designing the assessment was essential. Mrs. Smith elicited input from her students to create a rubric. She wanted the students to use this rubric as a guide while they completed the assignment. Again, the appeal of being included in the decision-making process was evident. Marie began their assignment immediately and was focused as she wrote. As Mrs. Smith predicted, the assessment confirmed that Marie learned the science objective while incorporating many of the language arts objectives for their grade level. 
Journal of Curriculum and Instruction (JoCl), July 2007, Volume 1, Number 1 (Stephanie G. Davis and Erika Gray)

Choice. Student interest is a key to developing student engagement. Hidi and Baird (1988) define interest as a person reacting to a situation or information of special personal significance. One way we can tap into student interest in our classrooms is by providing students with choice. By allowing student choice in the classroom environment, teachers are able to address students' individual interests (Randi \& Corno, 2000). During reading, student interest is of particular importance because students are expected to employ self-regulated strategies independently. There is no possible way for teachers to tap into all students' prior knowledge and experiences. Allowing students autonomy and control over their reading choices and learning enables this individual focus and engagement, although such strategies should always be accompanied by support and guidance from the teacher (Perry \& Drummond, 2002).

This sense of autonomy, many researchers argue, is a necessary component of student motivation and self-regulation (Deci, Schwartz, Sheinman, \& Ryan, 1981). When students are not involved in the instructional decisions in the classroom, they show less interest, which results in lowered motivation (Harter, 1996). "Research implies that teachers who guide choices and support student decision making while addressing important curricular goals may be more successful in promoting motivation for literacy" (Turner, 1995, p. 417), which in turn supports improved test scores.

High-challenge tasks. Educational tasks are at the heart of instruction in the classroom. Students spend the majority of their school hours working on tasks. Therefore, the message that these tasks send is significant. How do educators create environments that support students? Research suggests educators should offer high-challenge tasks that engage students over time (Harter, 1996; Markman, 1979; Mason et al., 2006; Miller, 2003; Zimmerman, 2000). Miller and Meece $(1997,1999)$ define high-challenge tasks as ones that are complex, extend over time, involve peer collaboration, and include student choice.

Classroom settings that foster these aspects are likely to enhance "flow" (Csikszentmihalyi, 1990), "a satisfied state of consciousness associated with intense concentration, effortless control, and deep enjoyment" (Paris \& Paris, 2001 , p. 94). In order for flow to occur during reading, students must continually monitor and adapt their understanding to successfully construct meaning from a text. Students will, therefore, be more likely to achieve flow when they regulate their reading. Environments that include these experiences have been shown to foster increased engagement and learning (Ames, 1992; Harter, 1996). If we want our students to be self-regulated learners, then we must establish environments that embrace high-challenge tasks.

Students faced with complex tasks are required to meet challenges that ask them to delve more deeply into their learning processes (Perry, et al., 2004). Note that complexity doesn't mean the tasks should be overly difficult; instead, it 

and Erika Gray)

is the task design that is complex. Complex tasks include multiple goals, large chunks of content, various resources, and varied problem-solving situations. High-challenge, complex tasks (Miller \& Meece, 1999) also allow various outcomes or products, which require students to integrate prior knowledge with new learning (Ames, 1992; Miller, 2003; Perry, et al., 2004).

Self-evaluation. Assessments are necessary in schools; without test results it would be impossible to identify students' needs or to evaluate overall progress. Due to the impact of No Child Left Behind, however, high-stakes tests have become the focus of evaluation. In a systematic review, Harlen and Crick (2000) found that an increased emphasis on testing has negative impacts on both teachers and students. When students fail tests, especially ones without a clear purpose, their perceptions of themselves suffer. Worse yet, when these results are shared with others even implicitly (i.e., "Oh, you should read with Mark today, he made a 4 on his test."), damage is done. "Not only do their own perceptions of themselves as learners suffer, but this perception becomes shared by their peers" (Harlen \& Crick, p. 171). Deci and Ryan's (1985) review of research suggests that students in environments driven by high-stakes tests do not feel in control of their learning. Grolnick and Ryan (1990) demonstrated that students learned less material when they were told its sole purpose was to prepare for an assessment; therefore, standardized assessment should not drive instruction. However, because the current test-driven policy is not likely to change, teachers must try to ameliorate the negative impact by including assessments that offer more positive effects. These assessments should include student input. To aid students in evaluating their own learning, assessments need to have a clear purpose and be connected in some way to personal goals that students have set. These assessments must be seen as attempts to inform, not judge (Ames, 1992).

Educators can conduct assessments in ways that create an environment conducive to self-regulated motivation. For years, educators have used the idea of allowing students to monitor their own progress as an effective behaviormodification intervention. For instance, having a student evaluate his behavior using an hourly chart promotes self-regulation. These charts are typically not posted or compared to others, but educators have found they have a positive effect on behavior. Ames (1992) would deem this strategy effective because the student is aware of the purpose of the chart. In addition, this strategy involves the student in evaluating his or her own progress. Similarly, Paris and Winograd (1990) suggest that students should chart evidence of cognitive growth. These strategies provide students with the opportunity to see themselves as capable. Activities such as the high-challenge tasks described in the section above, can embed such self-evaluation opportunities in everyday learning experiences. Offering tasks that include student responsibility to monitor their own progress is a particularly effective strategy (Perry, 1998; Perry, Turner, \& Meyer, 2006). Similarly, assessments that evaluate learning in relation to students' personal goals positively impact perceptions of their competence (Zimmerman, 2000). 
Journal of Curriculum and Instruction (JoCl), July 2007, Volume 1, Number 1 (Stephanie G. Davis and Erika Gray)

Likewise, reflection and self-evaluation help determine if goals were met. This informs judgments that can help guide further decisions, whether the decisions are for the immediate future or long range planning.

Zimmerman (1998) emphasizes that students who evaluate their performance are successful at self-regulating. Students who are unaware of the need to self-evaluate tend to have difficulty in regulating their learning. Feedback from teachers during this phase can help train students to determine appropriate goals and future work (Deci, Vallerand, Pelletier, \& Ryan, 1991). Fortunately, during most of the year, educators have control over the assessments they give children and can employ assessments that will help shape self-regulated learners. Non-threatening evaluation practices that encourage students to focus on personal progress and view errors as opportunities to learn are most beneficial to enhancing self-regulation (Perry, et al., 2004). "Self-assessment involves the internalization of standards so students can regulate their own learning" (Turner, 1995, p. 27). Although we know that high-stakes testing is a significant aspect of education today, it is the instruction that leads up to this that matters and determines how students perform. What educators can do is provide instructional situations that include feedback and are tied to student learning.

\section{Developing Self-Regulated Learners}

Because of the value of self-regulation for supporting student motivation and achievement, it is crucial that effective paths for developing self-regulation among students are identified. Social cognitive theory suggests a reciprocal interaction between the environment, the person, and his or her behavior (Bandura, 1986) as a significant influence on such student development. The theory highlights student learning through modeling, making teachers' abilities to model and reflect self-regulated learning in their teaching important. The ability to create students who are metacognitive and ultimately self-regulated during reading comprehension is therefore tied to teachers' self-regulation. It becomes imperative that teachers develop skills of self-regulation for themselves.

Self-regulated teachers have the ability to become decision makers, reflective practitioners, and independent learners (Randi, 2004). If the purpose of professional development is to create teachers who are goal directed and monitor their own behavior to adjust and solve problems, then we are striving to create teachers who are self-regulated (Corno, 2001; Paris \& Paris, 2001). Teachers who have characteristics of self-regulated learners are open to gaining different perspectives and seek support that will help them face instructional challenges (Butler, Lauscher, Jarvis-Selinger, \& Beckingham, 2004). Instructional challenges require a shift in conceptual knowledge, not just memorization of procedures (Butler, et al.). In order for teachers to change their thinking and beliefs, they must become more self-regulated. By so doing, they not only achieve benefits for themselves, but they also provide the requisite model for their students to learn the same skills. 
Journal of Curriculum and Instruction (JoCl), July 2007, Volume 1, Number 1 (Stephanie G. Davis and Erika Gray)

See Figure 2 for an example of how Marie's teacher supports selfregulated learning and Figure 3 for an illustration of how both Marie and Mrs. Smith reflect Zimmerman's three phases in the cycle of developing selfregulatory skill $(2000,2002)$.

Figure 2

\section{Mrs. Smith: A Self-Regulated Teacher}

Mrs. Smith teaches fourth grade with 21 students in her class. Mrs. Smith uses the fourth grade curriculum to plan for instruction. Although she plans instruction appropriate for preparing her students to be successful on end-of-grade tests, she also knows that she must address motivational aspects of learning.

Mrs. Smith knows that one of her literacy objectives for the year is to have students read a variety of genres, as indicated in the state's required course of study. The curriculum plays a large role in Mrs. Smith's goals for herself and her students, but she also thinks about each child individually to determine how she can work with each to reach full potential.

Mrs. Smith self-regulates by thinking of ways that she, as a teacher, wants to grow. Last year Mrs. Smith set up guided reading groups and chose books for students based on their levels. This year she is trying something new with guided literature circles. By incorporating student choice and collaboration, Mrs. Smith sets up activities that support high-challenge tasks.

She is implementing this new strategy with another fourth grade teacher in a collaborative effort. In this effort, the two teachers have opportunities to problem solve and gain differing perspectives. The teachers meet weekly to discuss their difficulties and progress. Through these meetings Mrs. Smith is evaluating her own progress as well as her students' progress in becoming more self-regulated. 
Journal of Curriculum and Instruction (JoCl), July 2007, Volume 1, Number 1 (Stephanie G. Davis and Erika Gray)

Figure 3

\begin{tabular}{|c|c|c|}
\hline \multicolumn{3}{|c|}{ Marie and Mrs. Smith as Self-Regulated Learners } \\
\hline $\begin{array}{l}\text { Zimmerman's } \\
\text { Three Phases }\end{array}$ & Marie's Task & Mrs. Smith's Tasks \\
\hline $\begin{array}{l}\text { Forethought Phase } \\
\text { (Goal Setting \& } \\
\text { Strategic Planning) }\end{array}$ & $\begin{array}{l}\text { Writes down prior } \\
\text { knowledge about polar } \\
\text { bears. } \\
\text { Uses at least two different } \\
\text { resources to determine } \\
\text { the validity of prior } \\
\text { knowledge. } \\
\text { Writes a paragraph } \\
\text { synthesizing prior } \\
\text { knowledge with any new } \\
\text { learning. }\end{array}$ & $\begin{array}{l}\text { Plans to implement new } \\
\text { ideas with literature circle } \\
\text { that incorporates high- } \\
\text { challenge tasks, choice, } \\
\text { appropriately leveled text, } \\
\text { and collaboration with } \\
\text { fourth grade students. } \\
\text { Collects professional } \\
\text { reading and resources to } \\
\text { support her efforts. }\end{array}$ \\
\hline $\begin{array}{l}\text { Performance Phase } \\
\text { (Self-instruction, } \\
\text { imagery, attention } \\
\text { focusing, strategy } \\
\text { tasks) }\end{array}$ & $\begin{array}{l}\text { Participates for one hour a } \\
\text { day in literature circle } \\
\text { collaborative work. } \\
\\
\text { Uses metacognitive } \\
\text { strategies to monitor and } \\
\text { repair understanding } \\
\text { during reading. }\end{array}$ & $\begin{array}{l}\text { Attends weekly } \\
\text { collaborative meetings } \\
\text { with another fourth grade } \\
\text { teacher to problem solve } \\
\text { and celebrate successes. } \\
\text { Monitors and adjusts } \\
\text { teacher behavior and } \\
\text { initiatives as needed to } \\
\text { support student learning. }\end{array}$ \\
\hline $\begin{array}{l}\text { Self-Reflection } \\
\text { Phase } \\
\text { (Self-evaluation of } \\
\text { performance) }\end{array}$ & $\begin{array}{l}\text { Collaborates with a } \\
\text { research partner to } \\
\text { discuss prior knowledge } \\
\text { and new knowledge, and } \\
\text { to construct a non-fiction } \\
\text { book page. } \\
\text { Evaluates performance } \\
\text { and discusses with peers } \\
\text { understandings of texts } \\
\text { and assignments. }\end{array}$ & $\begin{array}{l}\text { Reflects and sets new } \\
\text { goals for self and students } \\
\text { at various points in the } \\
\text { year. }\end{array}$ \\
\hline
\end{tabular}


Journal of Curriculum and Instruction (JoCl), July 2007, Volume 1, Number 1 (Stephanie G. Davis and Erika Gray)

\section{Professional Development Strategies that Develop Self-Regulation}

Because of the central role of teacher self-regulation, experiences that enable the development of this skill are essential considerations for professional development. Perry, Walton, and Calder (1999) developed a model for teachers to identify their needs and their students' needs to encourage self-regulated learning. The framework suggests the value of experiences that parallel the needs students have for the development of self-regulation, including setting goals, designing and implementing high-challenge activities, and monitoring and evaluating progress.

Social constructivist theory emphasizes an essential component of such professional development focusing on self-regulation. This perspective holds that knowledge is constructed through social interaction and is a shared experience rather than an individual one (Vygotsky, 1978). Teachers need to be involved in sharing and reflecting on their practices with their colleagues. Teachers who work in isolation may not be aware of the need to make changes in their instructional practices. Collaboration among teachers has been widely studied as a remedy to the isolation that many teachers feel. Working with others creates a professional learning community that holds members accountable while sustaining momentum during "inevitable challenges" (Butler, et al., 2004). Communication networks increase when staff members feel closely linked to each other (Bakkenes, de Brabander, \& Imants, 1999). Additionally, collaboration reveals deeper reflection and inquiry (Huffman \& Kalnin, 2003). Working together allows for incremental changes in classroom instruction and provides support for the challenges that teachers face with implementing new ideas and strategies; therefore, designing professional development that involves such collaboration can develop self-regulated teachers by providing more time, more talk, and situations that are tied to individual teaching contexts (Anders, Hoffman, \& Duffy, 2000; Thomas, Wineburg, Grossman, Myhre, \& Woolworth, 1998).

Researchers have suggested various models for such professional development, including study groups, inquiry groups, lesson plan study, and other collaborative initiatives. These types of collaborative initiatives involve equity, mutual participation, and problem solving in pursuit of common goals (Burbank \& Kauchak, 2003; Butler, et al., 2004). Additionally, they provide meaningful material and subject matter for teachers (Butler, et al.; Rock \& Wilson, 2005). These groups involve teachers bringing current issues to the table for discussion and implementation. Instructional principles that acknowledge and incorporate learners' beliefs and knowledge are also embedded in the constructivist theory (Florio-Ruane, Raphael, Highfield, \& Berne, 2002; Scanlon, Gallego, Duran, \& Reyes, 2005). Lefever-Davis, Wilson, Moore, Kent, \& Hopkins (2003) support collaboration as an avenue to achieve meaningful inquiry.

Because study groups serve as a model for teachers to work collaboratively, they may be especially effective at supporting self-regulated 
Journal of Curriculum and Instruction (JoCl), July 2007, Volume 1, Number 1 (Stephanie G. Davis and Erika Gray)

teachers. Recent research (Perry et al., 1999; Perry et al., 2004) reveals teachers that work collaboratively in study groups are able to solve problems. What appears essential is that such professional development experiences must provide opportunities for teachers to become more self-regulated and drive their own learning and motivation to constantly transform their instructional practices.

\section{Future Research}

Pintrich and DeGroot (1990) found, in a study of 173 seventh graders, that a student's ability to self-regulate his or her learning was the most predictive measure of performance; however, similar research is limited. Future research regarding self-regulation is needed for both students and teachers. In this era of high-stakes testing, further research is essential to convince administrators and national, state and local policymakers that this type of educational environment is just as important as, and potentially more productive than, cognitive test preparation.

Much of the research on self-regulated learning has been conducted with upper elementary-aged students (Perry \& VandeKamp, 2000), yet students who are able to read a text at any level are regulating their behavior to some degree during reading. Additionally, building a foundation for mastery learning early and having students enter the testing grades with a self-regulated learning orientation may be another avenue to increasing test scores. Stipek, Feiler, Daniels, and Milburn (1995) took a positive step in that direction when they found that four to six year olds in child-centered classrooms demonstrated self-regulated learning attitudes and behaviors. Similar to Miller and Meece's (1999) high-challenge tasks, these rooms allowed for diverse tasks that were connected to children's prior experiences and included meaningful peer interaction.

Future research is needed to establish the effects of teacher selfregulation on instructional practices as well as student learning. Because of the pivotal role played by self-regulation, it is essential that such research efforts are expanded. Research is needed to better understand the relationship between self-regulation and student achievement in reading. More specifically, effective use of student goals, tasks, and assessments associated with self-regulation must be better substantiated and made available to teachers, administrators, and policymakers.

\section{Conclusion}

Clearly, educators want their students to achieve; however in the age of high-stakes testing, educational goals have shifted to a "teach to the test" mentality. Unfortunately, when teachers are pressured to define learning in terms of test scores, it frequently results in a narrowing of the curriculum and difficulty creating environments that foster self-regulation. 
Journal of Curriculum and Instruction (JoCl), July 2007, Volume 1, Number 1 (Stephanie G. Davis and Erika Gray)

Research has documented the evidence of intrinsic motivation in selfregulated students (Perry, Turner, \& Meyer, 2006). They set goals, monitor progress, and reflect on outcomes (Zimmerman, 2002). These benefits occur when students are in an environment that helps to shape these behaviors (Ames, 1992; Blumenfeld, 1992; Zimmerman, 2000).

Self-regulation is not acquired; it is shaped and developed through participation in environments that provide students and teachers with opportunities to be in control of their own learning. When students and teachers begin to take responsibility for planning, monitoring, and evaluating their own learning processes, self-regulation is fostered, and all areas of schooling are improved. Therefore, as educators we must look beyond the success of passing a standardized test and strive to develop learning environments that support high level thinking skills and self-regulation, which have rich and multiple benefits far greater than test scores.

\section{References}

Ames, C. (1992). Classrooms: Goals, structures, and student motivation. Journal of Educational Psychology, 84, 261-271.

Anders, P., Hoffman, J., \& Duffy, G. (2000). Teaching teachers to teach reading: Paradigm shifts, persistent problems, and challenges. In M. Kamil, R. Barr, \& P. D. Pearson (Eds.), Handbook of reading research, Vol. III. (pp. 719-742). Mahwah, NJ: Erlbaum.

Au, K. H. (1997). A sociocultural model of reading instruction: The Kamehameha Elementary Education Program. In S. Stahl \& D. Hayes (Eds.), Instructional models in reading (pp.181-202). Mahwah, NJ: Lawrence Erlbaum Associates.

Bakkenes, I., de Brabander, C., \& Imants, J. (1999). Teacher isolation and communication network analysis in primary schools. Education Administration Quarterly, 35, 166-202.

Bandura, A. (1986). Social foundations of thought and action: A social cognitive theory. Englewood Cliffs, NJ: Prentice-Hall.

Blumenfeld, P. C. (1992). Classroom learning and motivation: Clarifying and expanding goal theory. Journal of Educational Psychology, 84, 272-281.

Brophy, J. (1987). On motivating students. In D. Berliner \& B. Rosenshine (Eds.), Talks to teachers (pp. 201-245). New York: Random House. 
Journal of Curriculum and Instruction (JoCl), July 2007, Volume 1, Number 1 (Stephanie G. Davis and Erika Gray)

Burbank, M., \& Kauchak, D. (2003). An alternative model for professional development: Investigations into effective collaboration. Teaching and Teacher Education, 19, 499-514.

Butler, D., Lauscher, H., Jarvis-Selinger, S., \& Beckingham, B. (2004). Collaboration and self-regulation in teachers' professional development. Teaching and Teacher Education, 20, 435-455.

Corno, L. (2001). Self-regulated learning: A volitional analysis. In B. Zimmerman \& D. Schunk (Eds.), Self-regulated learning and academic achievement: Theory, research, and practice, (Vol. II, 111-142). Mahwah, NJ: Lawrence Erlbaum Associates.

Csikszentmihalyi, M. (1975). Beyond boredom and anxiety: The experience of play in work and games. San Francisco: Jossey-Bass.

Csikszentmihalyi, M. (1990). Flow: The psychology of optimal experience. New York: Harper Collins.

Deci, E. L., \& Ryan, R. M. (1985). Intrinsic motivation and self-determination in human behavior. New York: Plenum Press.

Deci, E. L., Schwartz, A. J., Sheinman, L., \& Ryan, R. M. (1981). An instrument to assess adults' orientation toward control over autonomy with children. Journal of Educational Psychology, 73, 642-650.

Deci, E. L., Vallerand, R. J., Pelletier, L. G., \& Ryan, R. M. (1991). Motivation and education: The self-determination perspective. Educational Psychologist, 26, 325-346.

Dweck, C. S., \& Reppucci, N. D. (1973). Learned helplessness and reinforcement responsibility in children. Journal of Personality and Social Psychology, 25, 109-116.

Florio-Ruane, S., Raphael, T., Highfield, K., \& Berne, J. (2002). Reengaging youngsters with reading difficulties by means of innovative professional development. In D. Strickland \& M. Kamil (Eds.), Improving reading achievement through professional development (pp. 129-148). Norwood: Christopher-Gordon.

Galda, L., \& Guice, S. (1997). Response-based reading instruction in the elementary grades. In S. Stahl \& D. Hayes (Eds.), Instructional models in reading (pp.311-330). Mahwah, NJ: Lawrence Erlbaum Associates. 
Journal of Curriculum and Instruction (JoCl), July 2007, Volume 1, Number 1 (Stephanie G. Davis and Erika Gray)

Grolnick, W. S., \& Ryan, R. M. (1990). Self-perceptions, motivation, and adjustment in children with learning disabilities: A multiple group comparison study. Journal of Learning Disabilities, 23, 177-184.

Guthrie, J. T., Wigfield, A., Barbosa, P., Perencevich, K. C., Taboada, A., Davis, $M$. et al. (2004). Increasing reading comprehension and engagement through concept-oriented reading instruction. Journal of Educational Psychology, 96, 403-423.

Harlen, W., \& Crick, R. D. (2000). Testing and motivation for learning. Assessments in Education: Principles, Policy, \& Practice, 10, 169-207.

Harter, S. (1996). Teacher and classmate influences on scholastic motivation, self-esteem, and level of voice in adolescents. In J. Juvonen \& K. R. Wentzel (Eds.), Social motivation: Understanding children's school adjustment (Chapter 2: 11-42). New York: Cambridge.

Hidi, S., \& Baird, W. (1988). Strategies for increasing text-based interest and students' recall of expository texts. Reading Research Quarterly, 23, 465483.

Huffman, D., \& Kalnin, J. (2003). Collaborative inquiry to make data based decisions in schools. Teaching and Teacher Education, 19, 569-580.

Kaplan, A., \& Maehr, M. L. (2002). Adolescents' achievement goals: Situating motivation in sociocultural contexts . In F. Frank Pajares \& T. Urdan (Eds.), Academic motivation of adolescents (pp. 125-168). Connecticut, Information Age Publishing.

Lefever-Davis, S., Wilson, C., Moore, E., Kent, A., \& Hopkins, S. (2003). Teacher study groups: A strategic approach to promoting students' literacy development. The Reading Teacher, 56, 782.

Markman, E. M. (1979). Realizing that you don't understand: Elementary school children's awareness of inconsistencies. Child Development, 50, 643-655.

Mason, L. H., Snyder, K. H., Sukhram, D. P., \& Kedem, Y. (2006). TWA + PLANS strategies for expository reading and writing: Effects for nine fourth-grade students. Exceptional Children, 73, 69-89.

Midgley, C., Feldlaufer, H., \& Eccles, S. (1988). The transition to junior high school: Beliefs of pre- and posttransition teachers. Journal of Youth and Adolescence, 17, 543-562. 
Journal of Curriculum and Instruction (JoCl), July 2007, Volume 1, Number 1 (Stephanie G. Davis and Erika Gray)

Miller, S. D. (2003). How high- and low-challenge tasks affect motivation and learning: Implications for struggling learners. Reading and Writing Quarterly: Overcoming Learning Difficulties, 19, 39-57.

Miller, S. D., \& Meece, J. L. (1997). Enhancing elementary students' motivation to read and write: A classroom intervention study. Journal of Educational Research, 90, 286-299.

Miller, S. D., \& Meece, J. L. (1999). Third graders motivational preferences for reading and writing tasks. The Elementary School Journal, 100, 19-35.

Paris S. G., \& Paris A. H. (2001). Classroom application of research on selfregulated learning. Educational Psychologist, 36, 89-101.

Paris, S. G., \& Winograd, P. (1990). Improving the assessment of literacy. The Reading Teacher, 45, 108-117.

Perry, N. (1998). Young children's self-regulated learning and the contexts that support it. Journal of Educational Psychology, 90, 715-729.

Perry, N., \& Drummond, L. (2002). Helping young students become selfregulated researchers and writers. The Reading Teacher, 56, 298-310.

Perry, N. E., Nordby, C. J., VandeKamp, K. O. (2003). Promoting self-regulated reading and writing at home and school. The Elementary School Journal, 103, 317-338.

Perry, N., Philips, L, \& Dowler, J. (2004). Examining features of tasks and their potential to promote self-regulated learning. Teacher College Record, 106, $1854-1878$.

Perry, N. E., Turner, J. C., \& Meyer, D. K. (2006). Classroom contexts for motivating learners. In P. Alexander \& P. Winnie (Eds.), Handbook of educational psychology: Second edition, p. 327-348. Mahwah, NJ: Lawrence Erlbaum Associates.

Perry, N., \& VandeKamp, K. (2000). Creating classroom contexts that support young children's development of self-regulated learning. International Journal of Educational Research, 33, 821-843.

Perry, N., Walton, C., \& Calder, K. (1999). Teachers developing assessments of early literacy: A community of practice project. Teacher Education and Special Education, 22, 218-233.

Pintrich, P. R. (2000). The role of goal orientation in self-regulated learning. In M. Boekaerts, P. R. Pintrich, \& M. Zeidner (Eds.), Handbook of self-regulation (451-501). New York: Academic Press. 
Journal of Curriculum and Instruction (JoCl), July 2007, Volume 1, Number 1 (Stephanie G. Davis and Erika Gray)

Pintrich, P., \& DeGroot, E. (1990). Motivational and self-regulated learning components of classroom academic performance. Journal of Educational Psychology, 82, 33-40.

Randi, J. (2004). Teachers as self-regulated learners. Teachers College Record, $106,1825-1853$.

Randi, J., \& Corno, L. (2000). Teacher innovations in self-regulated learning. In M. Boekaerts, P. R. Pintrich, \& M. Zeidner (Eds.), Handbook of selfregulation (pp. 651-685). San Diego: Academic Press.

Rock, T., \& Wilson, C. (2005). Improving teaching through lesson study. Teacher Education Quarterly, 32, 77-92.

Rohrkemper, M., \& Corno, L. (1988). Success and failure on classroom tasks: Adaptive learning and classroom teaching. Elementary School Journal, 88, 297-312.

Scanlon, D., Gallego, M., Duran, G., \& Reyes, E. (2005). Interactive staff development supports collaboration when learning to teach. Teacher and Teacher Education, 28, 40-51.

Schunk, D. H. (2005). Commentary on self-regulation in school contexts. Learning \& Instruction, 15, 173-177.

Schunk, D. H., \& Rice, J. M. (1991). Learning goals and progress feedback during reading comprehension instruction. Journal of Reading Behavior, 23, 351-364.

Stipek, D., Feiler, R., Daniels, D., \& Milburn, S. (1995). Effects of different instructional approaches on young childrens' achievement and motivation. Child Development, 66, 209-223.

Thomas, G., Wineburg, S., Grossman, P., Myhre, O., \& Woolworth, S. (1998). In the company of colleagues: An interim report on the development of a community of teacher learners. Teaching and Teacher Education, 14, $21-$ 32.

Turner, J. C. (1995). The influence of classroom context on young children's motivation for literacy. Reading Research Quarterly, 30, 410-441.

Vygotsky, L. (1978). Mind in society: The development of higher psychological processes. Cambridge, MA: Harvard University Press. 
Journal of Curriculum and Instruction (JoCl), July 2007, Volume 1, Number 1 (Stephanie G. Davis and Erika Gray)

Zimmerman, B. J. (1998). Academic studying and the development of personal skill: A self-regulatory perspective. Educational Psychologist, 33, 73-86.

Zimmerman, B. J. (2000). Attaining self-regulation: A social cognitive perspective. In M. Boekaerts, P. R. Pintrich, \& M. Zeidner (Eds.), Handbook of self-regulation (pp. 13-39). New York: Academic Press.

Zimmerman, B. J. (2002). Self-regulation, achieving self-regulation: The trial and triumph of adolescence. In F. Frank Pajares \& T. Urdan (Eds.), Academic motivation of adolescents (pp. 1-28). Connecticut: Information Age Publishing.

Stephanie G. Davis is a doctoral student at the University of North Carolina at Greensboro. Her current research includes teachers' decision making during reading instruction, teacher development, and professional development. Before pursuing her doctorate full time, she worked as a curriculum facilitator and taught second and third grade in Greensboro, NC.

Erika Swarts Gray is a doctoral student at the University of North Carolina at Greensboro. She is a former reading specialist and fifth grade teacher. She is Nationally Board Certified in the area of early and middle childhood literacy. Her current research agenda includes university reading clinics, school-wide tutorial programs and more specifically the role of comprehension instruction in those settings. She is an alumnus of East Carolina University. 